\title{
Local Wisdom for Sustainable Forestry at Kalaodi Tidore Isle
}

\author{
Much. Hidayah Marasabessy ${ }^{1, *}$, Firlawanti Lestari Baguna ${ }^{1}$ \\ ${ }^{I}$ Department of Forestry, Faculty of Agriculture, Universitas Khairun, Ternate, Indonesia \\ "Corresponding author. Email: marasabessy@gmail.com
}

\begin{abstract}
The problem of forest conversion causes a diversity of forest resources, landscape forms and hills had changed and decrease. one effort to conserve forest resources can be done by integrating the local wisdom to manage the forest. The study aims to determine the local wisdom of the community in protecting the forest in Kalaodi, Tidore Isle. The research was conducted in November - December 2018, Kalaodi Village, Tidore Isle. The research method used is observation and interview. The results showed that the Tagafura Forest was one of the protected forests in Tidore Isle. The forest experienced pros and cons before being designated as a Protected Forest area. Local wisdom is still maintained and is directly related to efforts to conserve natural resources. One form of conservation in the Tagafura forest is the tradition of preserving nature, where people are not allowed to cut down or collect forest products, known as paca goya. Besides, the community also still believes in the prohibition in protecting nature, people have traditions that do not destroy and do not take the excess. For them taboos damage or cut down trees carelessly. For violators, they will get bobeto. Therefore, the need to integrate the local wisdom of the community in supporting conservation efforts by revitalizing and realizing the local wisdom which is given a legal basis as the basis of community strength, and the need for scientific research studies in supporting local wisdom as an effort to conserve the environment so that it has a positive impact on Kalaodi Community.
\end{abstract}

Keywords: local wisdom, sustainable, Bobeto, paca goya

\section{INTRODUCTION}

Forests support and provide various necessities of life through the use of subsistence products, such as food, animal feed, and medicinal plants; cash income derived from product sales; and more indirect ecological benefits such as the contribution of forests and trees to agricultural productivity [1], and contribute to preserving the culture and indigenous knowledge of local communities [2].

Local wisdom is local knowledge (local knowledge), local intelligence (local genius), and local policy (local wisdom). According to the Republic of Indonesia Law No.32 of 2009 concerning Environmental Protection and Management. It was the noble value that applies in the life order of the community which among others are used to protect and manage the environment in a sustainable manner.

Forest management based on customary rules in Maluku or known as sasi or restrictions. Sasi aims to maintain order in the management of hamlet and environmental resources, change the mindset of the community into an environmentally friendly society and the quality of the fruit produced is very high [3]. The Kalaodi community was called by Bobeto. Bobeto is the same as Sasi. Bobeto is part of the Paca Goya. Paca goya is local wisdom to protect the sustainable forest.

Sustainable management of sustainable forests is related to the use of natural resources and land that can be available continuously. However, the problem of forest conversion causes the diversity of forest resources, the shape of the landscape and the hills begin to change and decrease. Land use activities either convert natural forests to human life or practice forest landscape management and land human activities such as subsistence agriculture, intensification of agricultural land or expanding urban centers [4]. The reason is the degradation of forest resources and the lack of management efforts.

One of the efforts in sustainable forest management is not to cut down trees and replant trees such as areca nuts and bamboo as a sign of farming in the forest. The prohibition and local knowledge of the Kalaodi people in protecting the forest. If traditional knowledge is lost it will have a negative impact on forest resources because local communities have little knowledge about how to manage forest resources sustainably so efforts need to be made to determine the status of traditional knowledge.

\section{METHODS}

The research was conducted during November-December 2018. The population in the study was the community of Kalaodi Village, Tidore Isle City, the main respondents in the study were Jojau (Traditional Elder) Tidore and several communities were selected as informants with snowball 
sampling techniques. Data collected were analyzed using descriptive analysis.

\section{RESULTS AND DISCUSSION}

\section{a. The form of local wisdom of the Kalaodi people}

The Kalaodi community was still exists applying custom tradition, it is called local wisdom. in carrying out daily life without much depends on the existence of outside communities and is still subsistent. The livelihoods variation in Tidore community, especially the people who inhabit the Kalaodi area, generally working as annual farmers (cloves and nutmeg), artisans and entrepreneurs. Besides that, he also worked at the Tidore Isle City Government Institution.

Kalaodi has hills and valleys. The community occupies hills and valleys. But, several valleys and hills who did not inhabit because there are believed to be guards. Customary leaders maintain it. Local wisdom can not be separated from the historical background and influence on culture and customs. One form of local wisdom was sustainable forest management and household livelihoods through custom behavior. Trees and land were meaning as a holy place or ancestral place. Kalaodi community did the management of forest with various traditional rituals.

The results showed the traditional rituals of forest preservation and the environment around the forest in Kalaodi. The rituals are Paca Goya and Bobeto as follows; 1 Bobeto

Bobeto was a prohibition or agreement of Kalaodi traditional leaders. All the people obey Bobeto. Bobeto has a ban on who destroys nature, later it can be destroyed by nature Bobeto or the ancestral oath that is the agreement of a group of people with the environment based on human awareness about the importance of the natural environment for the survival of life [4]. People who accidentally or intentionally damage the forest or land will get a disaster or the consequences of actions that are not done. It is in line with the rules of the belief of local traditions. People who did cut and damaged trees can be affected by adverse effects such as illness.

2. Paca Goya

Paca goya is the traditional and cultural ritual in Kalaodi. The Community was protecting forest based on rules of tradition. Paca Goya is one of the local wisdom in protecting nature, especially the Tagafura forest. Paca Goya consists of two syllables with Paca and Goya. Paca means to clean. Goya means a place of worship or a prohibited area (forest), marked by a green area and a small house where rituals are usually used to tola bala.

The ritual means interaction between jinn/spirits (caliphs of the earth) and Humans (caliphs of the earth). Several traditions of Paca goya consists of kabata mayong, Kabata moro-moro and buku se dou.

\section{Kabata Mayong}

Kabata mayong was a song when cleaning the garden. Kabata mayong contains advice that encourages forest farmers in cleaning up customary land.

2. Kabata Moro-moro

Kabata Moro-moro regency contains religious advice, history, rituals in cultivating the land.

3. Buku se dou

Buku se dou means mountain and valley. It has the meaning of how to treat mountains and valleys in sustainably supporting human life.

Paca goya ritual means stop activities of human in the forest. Paca goya ritual activities for the last three days. the activities for three days, people were prohibited carrying out cooking, farming and hunting activities in the Tagafura forest or around of forest at Kalaodi Village. The condition is consistent with Etlegar that customary rules can protect natural resources [5].

\section{B. Alternative Cultural Development Strategies in conservation efforts}

The Kalaodi community's efforts in managing the forest are cultural or religious custom. The development of the religious system prioritizes customary institutions, obedient to customs, observing certain places, prohibited forest or Goya, prohibiting illegal forest encroachment or large trees. Alternative strategies for developing local knowledge in maintaining the sustainability of forests and household needs are;

1. Continuing the existence of traditional, institutional and legal law in the Kalaodi community, Tidore Isle.

2. Using customary institutions to manage forest damage,

3. In collaboration with the government to protect, maintain and utilize non-timber forest products

4. Assistance/guidance to the Kalaodi people and protect the forest from illegal logging.

5. Improved forest governance and negative activities to improve the welfare of communities around the forest.

\section{CONCLUSION}

The local wisdom of the community is still maintained and is directly related to efforts to manage natural resources. One form of management in the Kalaodi Tagafura forest is still a tradition of preserving nature, where people are not allowed to cut or take forest products or are known as paca goya. In addition, people also still believe in the prohibition in protecting nature, the community has a tradition of not being destructive and not taking excessively. For them, it is taboo to damage or cut down trees carelessly. For violators, it will be subject to bobeto. Therefore, the need to integrate local community wisdom in supporting management efforts by revitalizing and re-actualizing local wisdom which is given a legal basis as a basis for community strength, and the need for scientific research studies in supporting local wisdom so that it has a positive impact on the lives of the Kalaodi community. 


\section{ACKNOWLEDGMENT}

We are grateful to the School of Graduate Research, Khairun University for the Financial Support of This Study. We would like to thanks Headman of Kalaodi Village and Communities for your contribution to information.

\section{REFERENCES}

[1] Rasmussen, L. V., Watkins, C., \& Agrawal, A. 2017. Forest contributions to livelihoods in changing agriculture-forest landscapes. Forest Policy and Economics, 84, 1-8. DOI:10.1016/j.forpol.2017.04.010

[2] Baird I, G., Dearden P. 2003. Biodiversity conservation and resource tenure regimes: a case study from northeast Cambodia. Environmental Management. 32(5): 541-550. http://doi.org/cx5vnc

[3] Etlegar D. 2013. Peran Lembaga Adat Sasi Dalam Pengelolaan Sumberdaya Dusun di Negeri Allang Kecamatan Leihitu Barat, Kabaputen Maluku Utara. Skripsi. Institut Pertanian Bogor.

[4] Foley, J. A. 2005. Global Consequences of Land Use. Science, 309(5734), 570-574. DOI:10.1126/science.1111772.

[5] Teng, I., 2017. Bobeto sebuah nilai kearifan lokal pembentuk ruang ritual antara manusia dengan alam di Kalaodi-Tidore. Jurnal Local Wisdom, 9 (1):12-22.

https://doi.org/10.26905/lw.v9i1.1863 